Original Research Article

\title{
Evaluation of anti-inflammatory effect of aqueous extract of Aloe vera in Albino rats
}

\author{
Devarsi Choudhury*, Dolly Roy
}

Department of Pharmacology, Silchar Medical College and Hospital, P.O. Ghongoor 788014, Assam, India

Received: 25 August 2016 Accepted: 26 September 2016

\section{*Correspondence to:}

Dr. Devarsi Choudhury, Email: drdevarsi@gmail.com

Copyright: (C) the author[s], publisher and licensee Medip Academy. This is an openaccess article distributed under the terms of the Creative Commons Attribution NonCommercial License, which permits unrestricted noncommercial use, distribution, and reproduction in any medium, provided the original work is properly cited

\section{ABSTRACT}

Background: The study evaluated the anti-inflammatory effect of the aqueous extract of Aloe vera [AEAV] leaves. AEAV was prepared by the Soxhlet apparatus and $500 \mathrm{mg} / \mathrm{kg}$ body weight was used.

Methods: To screen for acute inflammation by carrageenan induced rat paw edema method, eighteen healthy albino rats weighing 150-200 gm each were used. They were divided in three groups with six animals in each group. At the $1 \mathrm{st} \mathrm{hr}, 2 \mathrm{nd}$ hour, 3rd hour and the 4th hour, the test drug i.e. AEAV [aqueous extract of Aloe vera] showed $26.92 \%, 41.6 \%, 44.44 \%$ and $48.21 \%$ inhibition of edema formation, whereas the standard drug Indomethacin $[10 \mathrm{mg} / \mathrm{kg}]$ showed $53.85 \%, 61.11 \%, 66.67 \%$ and $71.43 \%$ inhibition respectively. Reduction of paw edema formation was highly significant in both Aloe vera and Indomethacin.

Results: In Granuloma pouch method for subacute inflammation, the chemical used was $1 \mathrm{ml}$ of $20 \%$ carrageenan suspension in sesame oil. On the 5th day pouch is opened, exudates measured. Both Aloe vera and Indomethacin showed highly significant inhibition of exudate formation.

Conclusions: In Adjuvant arthritis method for chronic inflammation, paw edema of the injected and the non-injected were measured on the 5th day and the 21 st day respectively. Arthritic index was measured on the 21 st day. These results were highly significant for AEAV and Indomethacin in comparison with the control. The results for the arthritic index were highly significant for both Aloe vera and Indomethacin. It is easily illustrated that the herbal plant Aloe vera at the dose of $500 \mathrm{mg} / \mathrm{kg}$ demonstrated significant anti-inflammatory effect against all the experimental methods on inflammation.

Keywords: Aloe vera, AEAV, Carrageenan, Granuloma, Inflammation

\section{INTRODUCTION}

Inflammation is a protective response projected to do away with the initial cause of cell injury as well as the necrotic cells and tissues resulting from the original offense. $^{1}$ Inflammation participate importantly in host defences against infectious agents and injury, but it also contributes to the pathophysiology of many chronic diseases. A coordinated series of common effector mechanisms of inflammation contribute to tissue injury, oxidative stress, remodelling of the extracellular matrix, angiogenesis, and fibrosis in diverse target tissues. ${ }^{2}$ Acute inflammation describes the change taking place in micro vascular circulation amplified vascular permeability and exudation of fluids. Subacute inflammation is the transient phase lying in between the acute and the subacute phase. Chronic inflammation follows the initiation of repair of acute inflammation. There is constant production of collagen and scarring. Lymphohistiocytic infiltration accompanied by capillaries in an edematous stroma and increasing numbers of fibroblasts is called granulation tissue. ${ }^{3}$

The plant of concern in this study is Aloe vera. Aloe is known and is as old as the human civilization. Aloe is said to have been a favourite herb of Cleopatra. Perhaps the world's first cosmetics entrepreneur, Cleopatra popularized many famous beauty products, including milk and oats for bathing and aloe for skin care. ${ }^{4}$

Aloe vera is rich in minerals, vitamins, amino acids, polysaccharides, enzymes and lipids. In some villages it is even used to control gastro-intestinal parasites in chickens. ${ }^{5}$ Medicinal plants are opted to commercial 
drugs due to the exorbitant cost of commercial drugs, residual effects, parasites resistance and inaccessibility to most farmers. The pharmacological activities of the plant have been evaluated on the leaf gel and the pulp worked on Aloesin derivatives that are reported to possess strong DPPH [Diphenyl-2-Picryl Hydrazyl] radical and superoxide anion scavenging activities. ${ }^{5}$ There are approximately 500 species of the genus Aloe, of which 160 are indigenous to South Africa. ${ }^{6}$ Aloe vera Gel obtained from this plant is widely used for the external treatment of minor wounds, disorders, burns, bruises, and abrasions and even in cosmetics industry as a hydrating ingredient. $^{7}$

The discovery of a second cyclooxygenase has provided fresh impetus to the search for new anti-inflammatory drugs. ${ }^{8}$ NSAIDs have taken an edge over controlling inflammation as it inhibits the cyclooxygenase enzyme, but research is going on for the discovery of other antiinflammatory agents with minimal side effects. Aloe contains the enzymes carboxypeptidase and bradykinase, both of which have been shown to relieve pain and decrease inflammation and swelling. ${ }^{6}$

The present study was conducted to observe the antiinflammatory effect of AEAV after proper approval from the Institutional Animal Ethics Committee [IAEC]. The objectives of the current study are as follows:

- To determine the anti-inflammatory activity of AEAV against acute inflammation by Carrageenan induced rat paw edema method.

- To determine the anti-inflammatory activity of AEAV against sub-acute inflammation by Granuloma pouch method.

- To determine the anti-inflammatory activity of AEAV against chronic inflammation by Adjuvant arthritis method.

\section{METHODS}

\section{Toxicological evaluation of Aloe Vera in rats}

The study on the toxicological profile of Aloe vera was done by Saritha V and Anilakumar KR in Wistar rats. A multiple oral administration of the extract at single dose of $4,8,16 \mathrm{~g} / \mathrm{kg}$ body weights for 14 days did not produce signs of toxicity, behavioural appearances, changes on gross appearance. The sub-acute toxicity was determined by administration of graded doses $[1,2,4,8$ and $16 \mathrm{~g} / \mathrm{kg}$ orally] of the extract daily for 6 weeks and the effects on body weight, organ weight, histology as well as serum biochemical parameters were estimated. Body weight of dosed and control rats increased throughout the duration of treatment. They demonstrated significantly no difference in serum concentrations of aspartate amino transferase, alanine amino transferase, alkaline phosphatase, total protein, albumin, urea, creatinine, total and direct bilirubin.

\section{Preparation of $A E A V$ \\ i] Collection and preservation of specimen}

The herbal plant of Aloe vera was obtained from the campus of Silchar Medical College and Hospital, Assam. The fresh leaves of Aloe vera were air dried at room temperature, powdered by electrical grinder and kept in a tight container. The dried powder obtained was 174 grams.

\section{ii] Extraction of plant leaves}

The aqueous solvent was used in this study. The 174 grams of the dried powder was mixed with 1.7 liters of distilled water and was loaded in the thimble of Soxhlet apparatus at $70^{\circ} \mathrm{C}$ for $72 \mathrm{hr}$. The extracts obtained were then filtered using Whatmann No.1 paper. The residue thus obtained was allowed to evaporate in glass petri dishes in room environment. When completely dry, the extract was scraped out, weighed and stored for future use. After completion, the extracts were weighted and the percentage yield was calculated [initial weight of raw material / final weight of extract].

\section{Percentage yield calculation}

Weight of the dried powdered leaves $=174$ grams

Weight of the extract [semi solid mass] obtained $=20$ grams

Percentage yield $=11.5 \%$

Period of study was September 2014 to August 2015.

\section{Experimental animals used in the study}

The Albino [Wistar] rats used for the study were obtained from Chakraborty Enterprise, Kolkata. ${ }^{10}$ They were housed in polypropylene cages and kept under controlled room temperature $\left[24 \pm 2^{0} \mathrm{C}\right]$ having relative humidity of $60-70 \%$ in a $12 \mathrm{hr}$ light-dark cycle. The rats were given free access to standard laboratory diet and water. Animals were deprived of food but not water for four hours before the experiment.

\section{Criteria for experimental animals}

The experimental methods were carried out on:

- Healthy albino rats [Rattus norvegicus].

- Sex: of either sex.

- Body weight: 150-200 grams.

- Total number of animals used: Eighteen.

- Place used to keep the animals: Central Animal House, Silchar Medical College and Hospital, Assam.

- Diet: Standard animal diet with Bengal gram, wheat, Maize, bread and sufficient amount of water. 
- All the animals were taken care of under ethical consideration.

\section{Inclusion criteria}

- Animals weighing between 150-200 grams.

- Healthy animals with normal behaviour and activity.

- Previously unused rats.

\section{Exclusion criteria}

- Rats weighing less than 150 grams and more than 200 grams.

- Pregnant females and those that have delivered once.

- Previously used in other experiments.

\section{Drugs, equipment and materials used in the study}

Indomethacin, Carrageenan, Complete Freund's Complete Adjuvant [CFA], Normal saline, Sesame oil, Distilled water, Digital electronic weighing scale [GF400], Filter paper [Whatmann no. 1], Oral feeding gavage, Single use syringe, Soxhlet apparatus, Sterile surgical gloves, Volumetric flask [BOROSIL], and Glass petri dishes.

\section{Statistical analysis}

The results of all the three methods were expressed as Mean \pm SEM. Statistical analysis was determined using one-way analysis of variance [ANOVA] followed by Dunnett's t test. The results were calculated with the use of GraphPad Prism software.

\section{Experimental design for anti-inflammatory activity against acute inflammation}

The anti-inflammatory activity of AEAV against acute inflammation was done by carrageenan induced rat paw edema method.

\section{Materials used}

Drugs: Normal saline, AEAV, Indomethacin and carrageenan.

Equipment: Plethysmometer, tuberculin syringe, marker pen.

Table 1: Grouping and treatment schedule.

\begin{tabular}{|c|c|c|}
\hline Group & $\begin{array}{l}\text { Number } \\
\text { of animals }\end{array}$ & Treatment \\
\hline $\begin{array}{l}\text { A } \\
\text { [Control] }\end{array}$ & 6 & $\begin{array}{l}\text { Normal saline, } 10 \mathrm{ml} / \mathrm{kg} \text {, } \\
\text { orally, single dose. }\end{array}$ \\
\hline B [Test] & 6 & $\begin{array}{l}\text { AEAV[AEAV] } 500 \\
\mathrm{mg} / \mathrm{kg} \text {, orally, single dose. }\end{array}$ \\
\hline $\begin{array}{l}\text { C } \\
{[\text { Standard }]}\end{array}$ & 6 & $\begin{array}{l}\text { Indomethacin } 10 \mathrm{mg} / \mathrm{kg} \text {, } \\
\text { orally, single dose. }\end{array}$ \\
\hline
\end{tabular}

\section{Methods}

Healthy albino rats of either sex weighing 150-200 grams were used for the study. The animals were fasted overnight and received water ad libitum during the experiment. The animals were divided into three groups with six animals in each group.

The value of the assessment is less dependent on the apparatus but much more on the irritant being chosen. The animals are starved overnight. ${ }^{11}$ All the drugs were administered orally and the volume of medicaments kept constant at $10 \mathrm{ml} / \mathrm{kg}$ body weight of the animals. Acute inflammation was produced by sub-plantar injection of $0.1 \mathrm{ml}$ of freshly prepared $1 \%$ carrageenan suspension in normal saline in the left hind paw of rats in each group. The animals were treated with normal Saline, AEAV and Indomethacin in the respective groups, $1 \mathrm{hr}$ before carrageenan injection. The paw volume was measured plethysmometrically just before carrageenan injection i.e. at ' 0 ' $\mathrm{hr}$ and then at $1^{\text {st }}, 2^{\text {nd }}, 3^{\text {rd }}$ and $4^{\text {th }} \mathrm{hr}$ after carrageenan injection. $^{12,13}$ A mark was made on both the hind paws just below the tibio-tarsal junction so that every time the paw could be dipped in the column of the plethysmometer up to the mark to ensure a constant paw volume. Increase in paw edema was measured as the difference between the paw volume at ' 0 ' $\mathrm{hr}$ and paw volume at the respective hour. The percentage inhibition of the rat paw edema was calculated after each hour of carrageenan injection up to 4 hours by the formula described by Sudjarwo Agus. ${ }^{14}$

Percentage $[\%]$ inhibition $=$

$$
\frac{[\text { Control mean - Treated mean] x } 100}{\text { Control mean }}
$$

The data were subjected to statistical analysis using one way ANOVA followed by Dunnet's ' $\mathrm{t}$ ' test. $\mathrm{P}$ values $<0.05$ were considered significant.

\section{Experimental design for anti-inflammatory activity against sub-acute inflammation}

The anti-inflammatory activity of AEAV against subacute inflammation was tested by Granuloma pouch method. ${ }^{11,15-18}$

\section{Materials used}

Drugs: Normal Saline, AEAV, Indomethacin, 20\% carrageenan suspension in sesame oil.

Equipment: $20 \mathrm{ml}$ syringe with fine needle, feeding tube, towel.

\section{Methods}

Healthy albino rats were divided into three groups with six animals in each group. Rats were anaesthetized with 
ether and subcutaneous dorsal air pouches were then prepared at the backs, by injecting $20 \mathrm{ml}$ of air with the help of a fine needle, after proper shaving and disinfection. Then $1 \mathrm{ml}$ of $20 \%$ carrageenan suspension in sesame oil was injected into each pouch. $48 \mathrm{hr}$ later air was withdrawn from the pouch and $72 \mathrm{hr}$ later any resulting adhesions were broken. The animals were treated with Normal Saline, AEAV or Indomethacin in the respective groups for four days starting from the day of pouch formation. On the 5th day, the animals are sacrificed under ether anesthesia. The pouch is opened and exudates were sucked out and the amount measured in glass cylinders. The average values of the exudates of the control and the test groups were calculated. The percentage inhibition was then calculated for all the groups. The data were subjected to statistical analysis using one way ANOVA followed by Dunnet's ' $\mathrm{t}$ ' test. $\mathrm{P}$ values $<0.05$ were considered significant. ${ }^{15-19}$

\section{Experimental design for anti-inflammatory activity against chronic inflammation}

The anti -inflammatory activity of AEAV against chronic inflammation was tested by Adjuvant arthritis method in rats.

\section{Materials used}

Drugs: AEAV, Complete Freund's [CFA] adjuvant, Indomethacin and normal saline.

Equipment: Tuberculin syringe, Plethysmometer, Weighing machine, Feeding tube, towel.

\section{Methods}

Healthy albino rats were divided into three groups with six animals in each group. On day 1 , the animals were injected into the sub plantar region of the left hind paw with $0.1 \mathrm{ml}$ of CFA. Dosing with the test compounds or the standards to the respective groups was started on the same day and continued for 12 days. Paw volumes of both sides and the body weights were recorded on the day of injection. The paw volumes were measured plethysmographically as in the paw edema test. On day 5, the volume of the injected paw is measured again, indicating the primary lesion and the influence of therapeutic agent on this phase. The severity of the induced adjuvant disease is followed by measurement of the non-injected paw [secondary lesions] with a plethysmometer. Purposely, from day 13 to 21, the animals are not dosed with the test compound or the standard. On day 21, the body weight is determined again and the polyarthritis severity was graded on a scale of 0 4: $0=$ no swelling; $1=$ isolated phalanx joint involvement; $2=$ involvement of phalanx joint and digits; $3=$ involvement of the entire region down to the ankle; $4=$ involvement of entire paw, including ankle. The maximum joint score was 12 including 3 secondary arthritis paw for each rat. ${ }^{11,20}$

\section{Evaluation}

For primary lesions: The percent inhibition of paw volume of the injected left paw over control is measured at day 5 .

For secondary lesions: The percentage inhibition of paw volume of non-injected right paw over control is measured at day 21 .

An Arthritic Index is calculated as the sum of the scores as indicated above for each animal.

The volumes of all the medicaments were kept constant at $10 \mathrm{ml} / \mathrm{kg}$ body weight. Finally the data were subjected to statistical analysis using one way ANOVA followed by Dunnet's ' $\mathrm{t}$ ' test. $\mathrm{P}$ values $<0.05$ were considered significant. ${ }^{11,20}$

\section{RESULTS}

The anti-inflammatory properties of Aloe vera in the form of the aqueous extract were seen against the experimental models of acute, sub-acute and chronic inflammation. The experiments revealed significant difference between rat groups treated with the extract and that of the control.

\section{Anti-inflammatory activity against acute inflammation}

Carrageenan induced Rat Paw Edema test.

Table 2 shows the acute anti-inflammatory effect of the Groups A, B and C on Carrageenan induced Rat Paw Edema test in albino rats at the end of 1st, 2nd, 3rd and 4th hr. Group A [Control] showed the following increase: $0.26 \pm 0.02$ in the $1^{\text {st }} \mathrm{hr} ; 0.36 \pm 0.03$ in the $2^{\text {nd }} \mathrm{hr} ; 0.45 \pm 0.03$ in the $3^{\text {rd }} \mathrm{hr}$ and $0.56 \pm 0.02$ in the $4^{\text {th }} \mathrm{hr}$. Group B containing the test drug AEAV[AEAV] gave the following results: $0.19 \pm 0.01$ in the $1^{\text {st }} \mathrm{hr} ; 0.21 \pm 0.02$ in the $2^{\text {nd }} \mathrm{hr} ; 0.25 \pm 0.03$ in the $3^{\text {rd }} \mathrm{hr}$ and $0.29 \pm 0.02$ in the $4^{\text {th }} \mathrm{hr}$. The standard drug i.e. Group C [Indomethacin] showed $0.12 \pm 0.02$ in the $1^{\text {st }} \mathrm{hr} ; 0.14 \pm 0.01$ in the $2^{\text {nd }} \mathrm{hr} ; 0.15 \pm 0.01$ in the $3^{\text {rd }} \mathrm{hr}$ and $0.16 \pm 0.02$ in the $4^{\text {th }} \mathrm{hr}$.

Table 3 shows that the percentage inhibition of paw edema at the end of $1^{\text {st }}, 2^{\text {nd }}, 3^{\text {rd }}$ and $4^{\text {th }} \mathrm{hr}$ of Carrageenan injection was $26.92 \%, 41.67 \%, 44.44 \%$ and $48.21 \%$ for the AEAV at the dose of $500 \mathrm{mg} / \mathrm{kg}$ and $53.85 \%$, $61.11 \%, 66.67 \%$ and $71.43 \%$ for the test drug Indomethacin $[10 \mathrm{mg} / \mathrm{kg}]$ respectively. It was seen that the test drug AEAV produced increased inhibition of paw edema. Anti-inflammatory property of AEAV at the dose of $500 \mathrm{mg} / \mathrm{kg}$ was significant even at the end of $1^{\text {st }}$ hour but it was highly significant at the end of $2^{\text {nd }}, 3^{\text {rd }}$ and $4^{\text {th }}$ hr when compared to the control. On the other hand, 10 $\mathrm{mg} / \mathrm{kg}$ of the Standard drug [Indomethacin] produced highly significant $[p<0.01]$ anti-inflammatory effect at the end of $1^{\text {st }}, 2^{\text {nd }}, 3^{\text {rd }}$ and $4^{\text {th }}$ hour of carrageenan injection in comparison to the control. 
Table 2: The acute anti-inflammatory activity of AEAV on carrageenan induced Rat Paw Edema test in albino rats at the end of $1^{\text {st }}, 2^{\text {nd }}, 3^{\text {rd }}$ and $4^{\text {th }}$ hour.

\begin{tabular}{|llllll|}
\hline \multirow{2}{*}{ Groups } & Drug dose & \multicolumn{4}{l|}{ Mean increase in paw volume [Mean \pm SEM] [MI] } \\
\hline A [N.S.] & $10 \mathrm{ml} / \mathrm{kg}$ & $0.26 \pm 0.02$ & $0.36 \pm 0.03$ & $0.45 \pm 0.03$ & $0.56 \pm 0.02$ \\
\hline B [AEAV] & $500 \mathrm{mg} / \mathrm{kg}$ & $0.19 \pm 0.01$ & $0.21 \pm 0.02$ & $0.25 \pm 0.03$ & $0.29 \pm 0.02$ \\
\hline C [Indomethacin] & $10 \mathrm{mg} / \mathrm{kg}$ & $0.12 \pm 0.02$ & $0.14 \pm 0.01$ & $0.15 \pm 0.01$ & $0.16 \pm 0.02$ \\
\hline
\end{tabular}

Table 3: The percentage inhibition of paw volume by AEAV on carrageenan induced rat paw Edema test in albino rats at the end of $1^{\text {st }}, 2^{\text {nd }}, 3^{\text {rd }}$ and $4^{\text {th }} \mathrm{hr}$.

\begin{tabular}{|c|c|c|c|c|c|}
\hline \multirow[b]{2}{*}{ Groups } & \multirow[b]{2}{*}{$\begin{array}{l}\text { Drug } \\
\text { dose }\end{array}$} & \multicolumn{4}{|c|}{$\%$ Inhibition of paw volume } \\
\hline & & $\begin{array}{l}1^{\text {st }} \\
\text { hour }\end{array}$ & $\begin{array}{l}2^{\text {nd }} \\
\text { hour }\end{array}$ & $\begin{array}{l}3^{\text {rd }} \\
\text { hour }\end{array}$ & $\begin{array}{l}4^{\text {th }} \\
\text { hour }\end{array}$ \\
\hline A [N.S.] & $10 \mathrm{ml} / \mathrm{kg}$ & - & - & - & - \\
\hline $\begin{array}{l}\text { B } \\
\text { [AEAV] }\end{array}$ & $\begin{array}{l}500 \\
\mathrm{mg} / \mathrm{kg}\end{array}$ & 26.92 & 41.67 & 44.44 & 48.21 \\
\hline $\begin{array}{l}\text { C [Indom- } \\
\text { ethacin] }\end{array}$ & $\begin{array}{l}10 \\
\mathrm{mg} / \mathrm{kg}\end{array}$ & 53.85 & 61.11 & 66.67 & 71.43 \\
\hline
\end{tabular}

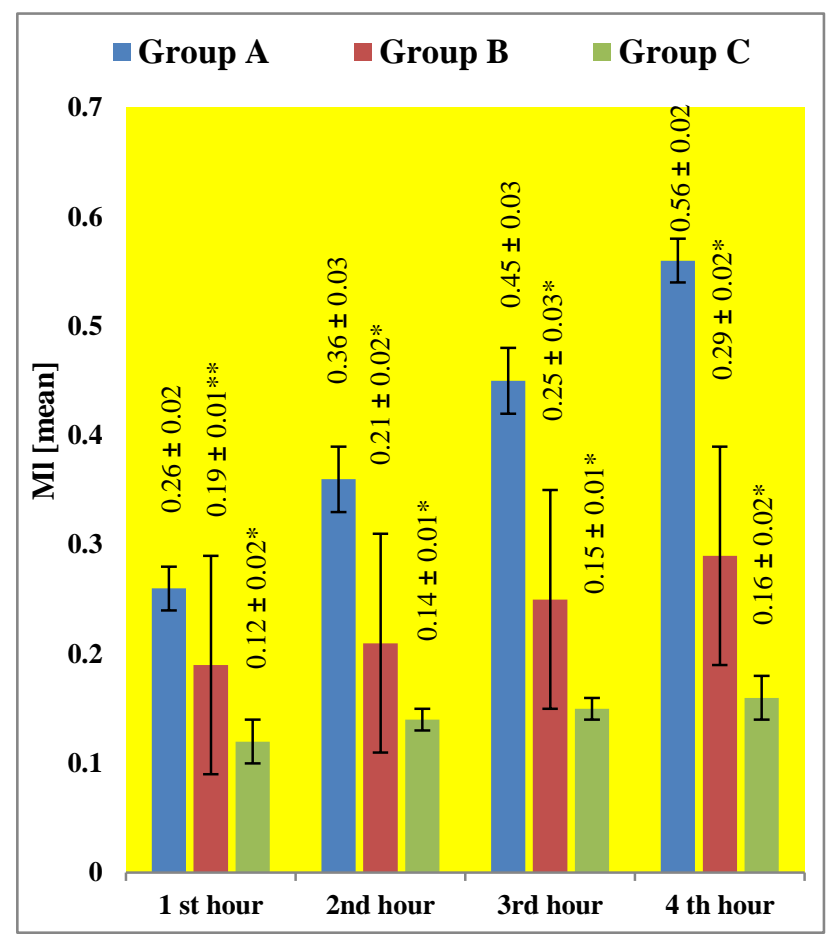

Results were presented as Mean \pm SEM $[\mathrm{n}=6]$. Group A: Normal saline [10ml/kg]; Group B: AEAV [500 mg/kg]; Group $\mathrm{C}$ : Indomethacin $[10 \mathrm{mg} / \mathrm{kg}] . * \mathrm{p}<0.01$ and $* * \mathrm{p}<0.05$.

Figure 1: Mean increase in paw Edema formation at the end of $1^{\text {st }}, 2^{\text {nd }}, 3^{\text {rd }}$ and $4^{\text {th }}$ hour of carrageenan injection.

\section{Anti-inflammatory activity against sub-acute inflammation}

Granuloma pouch method.

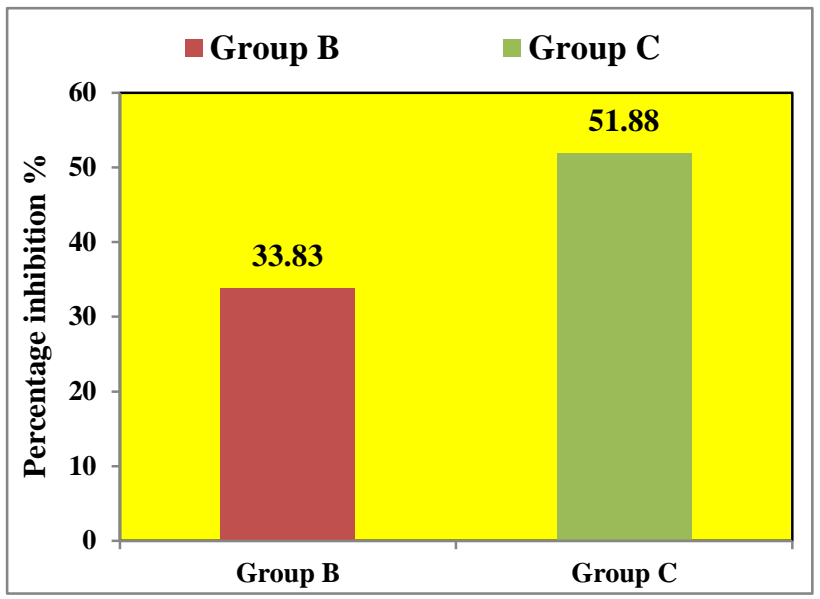

Group B: AEAV [500mg $/ \mathrm{kg}]$; Group C: Indomethacin $[10 \mathrm{mg} / \mathrm{kg}]$.

Figure 2: Percentage inhibition of exudate formation at the end of $5^{\text {th }}$ day.

Table 4: Anti-inflammatory activity of AEAV on subacute inflammation by Granuloma Pouch Method in albino rats.

\begin{tabular}{|lll|l|}
\hline Groups & $\begin{array}{l}\text { Drug } \\
\text { dose } \\
\text { P.O. }\end{array}$ & $\begin{array}{l}\text { Mean volume } \\
\text { of exudate } \\
\text { [Mean } \pm \text { sem] } \\
\text { in ml }\end{array}$ & $\begin{array}{l}\% \\
\text { Inhibition } \\
\text { of exudate } \\
\text { formation }\end{array}$ \\
\hline A [N.S.] & $10 \mathrm{ml} / \mathrm{kg}$ & $3.99 \pm 0.18$ & - \\
\hline B [AEAV] & $\begin{array}{l}500 \\
\mathrm{mg} / \mathrm{kg}\end{array}$ & $2.64 \pm 0.09 *$ & 33.83 \\
\hline $\begin{array}{l}\text { C [Indome- } \\
\text { thacin] }\end{array}$ & $\begin{array}{l}10 \\
\mathrm{mg} / \mathrm{kg}\end{array}$ & $1.92 \pm 0.11^{*}$ & 51.88 \\
\hline
\end{tabular}

$\mathrm{n}=6$ in each group; *p <0.01 when compared to control; ANOVA followed by Dunnet's multiple comparison test.

Table 4 gives us information about the mean exudates collected on the $5^{\text {th }}$ day. Group A i.e. Control shows an exudate amount of $3.99 \pm 0.18 \mathrm{ml}$. Group B i.e. test drug AEAV gives an amount of $2.64 \pm 0.09 \mathrm{ml}$ with a $33.83 \%$ inhibition of exudate formation. Group $\mathrm{C}$ i.e. standard 
drug generates an exudate of $1.92 \pm 0.11 \mathrm{ml}$, accounting for $51.88 \%$ inhibition of exudate formation. Both the test drug i.e. AEAV and the standard drug Indomethacin showed highly significant inhibition of exudate formation [p<0.01] when compared with the control.

\section{Anti-inflammatory activity against chronic inflammation}

Adjuvant induced arthritis method.

In the Table 5, paw volume of the injected paw was measured on the $5^{\text {th }}$ day following the administration of the respective drugs. Group A showed an increase of 1.11 $\pm 0.03 \mathrm{ml}$ on the $5^{\text {th }}$ day; Group B i.e. the test drug AEAV showed an increase of $0.89 \pm 0.02 \mathrm{ml}$ and Group C recorded an increase of $0.69 \pm 0.02 \mathrm{ml}$. Percentage inhibition for group B was $19.82 \%$ and for Group C it was $37.84 \%$. Thus $500 \mathrm{mg} / \mathrm{kg}$ of AEAV showed significant anti-inflammatory effect on primary lesions on $5^{\text {th }}$ day of adjuvant injection $[\mathrm{p}<0.01]$ when compared to the control. On the other side the standard drug Indomethacin at the dose of $10 \mathrm{mg} / \mathrm{kg}$ produced highly significant $[\mathrm{p}<0.01]$ anti-inflammatory effect on $5^{\text {th }}$ day in comparison to the control.

Table 5: Anti-inflammatory activity of AEAV on chronic inflammation by adjuvant induced arthritis method on $5^{\text {th }}$ day [injected paw].

\begin{tabular}{|llllll|}
\hline Groups & $\begin{array}{l}\text { Drug dose } \\
\text { [P.O.] }\end{array}$ & \multicolumn{2}{l|}{ Paw volume [Mean \pm SEM] $[\mathrm{MI}]$} & & $\begin{array}{l}\text { \% Inhibition } \\
\text { of paw Edema }\end{array}$ \\
\hline A [N.S.] & $10 \mathrm{ml} / \mathrm{kg}$ & $1.05 \pm 0.02$ & $2.17 \pm 0.04$ & $1.11 \pm 0.03$ & - \\
\hline B [AEAV] & $500 \mathrm{mg} / \mathrm{kg}$ & $1.03 \pm 0.02$ & $1.94 \pm 0.02$ & $0.89 \pm 0.02^{*}$ & 19.82 \\
\hline C [Indomethacin] & $10 \mathrm{mg} / \mathrm{kg}$ & $1.05 \pm 0.03$ & $0.89 \pm 0.02$ & $0.69 \pm 0.02^{*}$ & 37.84 \\
\hline
\end{tabular}

$\mathrm{n}=6$ in each group; * $\mathrm{p}<0.01$ when compared to control; ANOVA followed by Dunnet's multiple comparison test

Table 6: Paw volume [non-injected paw on the $21^{\text {st }}$ day].

\begin{tabular}{|lllll|l|}
\hline \multirow{2}{*}{ Groups } & $\begin{array}{l}\text { Drug dose } \\
{[\text { P.O.] }}\end{array}$ & \multicolumn{2}{l|}{ Paw volume $[$ Mean \pm SEM] $[M I]$} & & $\begin{array}{l}\text { \% Inhibition } \\
\text { of paw Edema }\end{array}$ \\
\hline A [N.S.] & $10 \mathrm{ml} / \mathrm{kg}$ & $1.06 \pm 0.02$ & $1.47 \pm 0.02$ & $0.42 \pm 0.02$ & ---- \\
\hline B [AEAV] & $500 \mathrm{mg} / \mathrm{kg}$ & $1.03 \pm 0.03$ & $1.18 \pm 0.03$ & $0.14 \pm 0.01$ & 66.67 \\
\hline C [Indomethacin] & $10 \mathrm{mg} / \mathrm{kg}$ & $1.06 \pm 0.03$ & $1.13 \pm 0.04$ & $0.07 \pm 0.01$ & 83.33 \\
\hline
\end{tabular}

$\mathrm{n}=6$ in each group; * $\mathrm{p}<0.01$ when compared to control; ANOVA followed by Dunnet's multiple comparison test.

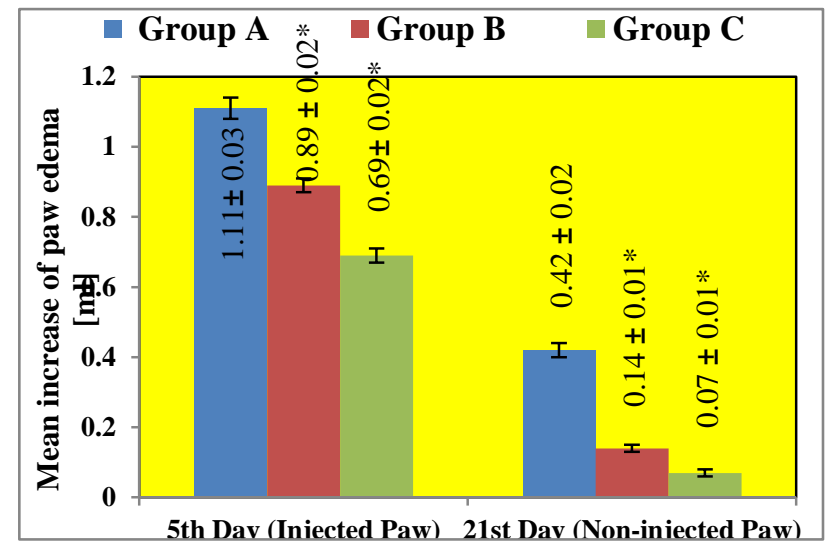

Results were presented as Mean \pm SEM $[\mathrm{n}=6]$. Group A: Normal saline [10ml/kg]; Group B: AEAV [500 mg/kg]; Group $\mathrm{C}$ : Indomethacin $[10 \mathrm{mg} / \mathrm{kg}] * \mathrm{p}<0.01$.

Figure 3: Effect of AEAV against complete Freund's adjuvant [CFA] induced paw Edema.

Table 7: Arthritic index on the 21st day.

\begin{tabular}{|lll|} 
Groups & $\begin{array}{l}\text { Drug dose } \\
\text { P.O. }\end{array}$ & $\begin{array}{l}\text { arthritis index on } \text { 21 }^{\text {st }} \\
\text { day [Mean } \pm \text { sem] }\end{array}$ \\
\hline A [N.S.] & $10 \mathrm{ml} / \mathrm{kg}$ & $10 \pm 0.73$ \\
\hline B [AEAV] & $500 \mathrm{mg} / \mathrm{kg}$ & $4 \pm 0.37^{*}$ \\
\hline C [Indomethacin] & $10 \mathrm{mg} / \mathrm{kg}$ & $3.33 \pm 0.49^{*}$ \\
\hline
\end{tabular}

$\mathrm{n}=6$ in each group; *p <0.01 when compared to control; ANOVA followed by Dunnet's multiple comparison test.

Table 6 shows the effect of AEAV on Freund's adjuvant induced rat paw Edema on $21^{\text {st }}$ day [non-injected paw]. The paw volume of the non- injected paw was measured on the $21^{\text {st }}$ day. The control Group A showed an increase of paw volume of $0.42 \pm 0.02 \mathrm{ml}$. The test drug AEAV i.e. Group B showed an increase of $0.14 \pm 0.01 \mathrm{ml}$ and the standard drug Indomethacin i.e. Group $\mathrm{C}$ showed an increase of $0.07 \pm 0.01 \mathrm{ml}$. The percentage inhibition for Group B was $66.67 \%$ and for Group C was $83.33 \%$. Both the test drug AEAV and the standard drug Indomethacin showed significant inhibition of paw Edema on the $21^{\text {st }}$ day.

The arthritic index for the control group, i.e. Group A was $10 \pm 0.73$ on the $21^{\text {st }}$ day. For the test drug i.e. Group 
B it was $4 \pm 0.37$ and for the standard drug Indomethacin, i.e. Group $C$ it was $3.33 \pm 0.49$. The results were highly significant for both the Group B and Group C when it was compared with the control Group A. We can conclude that the arthritic index showed a great improvement when it was calculated for both the test and standard groups.

\section{DISCUSSION}

The Carrageenan is known for its classic biphasic effect; the first phase is mediated by release of Histamine and Serotonin during the first hour and release of kinins up to 2.5 hours, while the second phase is mediated by release of Prostaglandins from 2.5 to 6 hours. It has been reported that the second phase is found to be sensitive to most of the clinically effective anti-inflammatory drugs. ${ }^{21}$

In the present study, the acute anti-inflammatory effect of Aloe vera by the Carrageenan induced paw edema method showed that Aloe vera at the dose of $500 \mathrm{mg} / \mathrm{kg}$ produced significant inhibition of paw edema [44.44\%] which was comparable with the standard drug Indomethacin. These results were concurrent with the study by Kshirsagar et al. They showed that Aloe emodin [AE] and carboxylic acid derivative of Aloe emodin [AEC] exhibited significant anti-inflammatory and antiarthritic activity. ${ }^{20}$ It reported that AE and AEC showed dose-dependent inhibition of second phase of Carrageenan induced rat paw edema, suggesting the inhibition of Prostaglandins release ${ }^{21}$. In another study by Egesie UG et al, they found out that aqueous extract of the Aloe produced significant anti-inflammatory effect as indicated by the decrease in paw oedema. ${ }^{22}$ Aqueous extract of the Aloe reduced the formalin-induced oedema significantly at the beginning of 3 hours when compared to the control group. ${ }^{3}$ Inhibition of inflammation was observed also in the Formaldehyde induced rat paw oedema and in the Histamine-induced oedema further supporting the presence of anti-inflammatory substances in the plant. ${ }^{23}$ Even the study by Bhattacharjee et al, on the test drug Aloe vera on Carrageenan induced paw edema showed a substantial effect by reducing paw swelling. They recorded an increased level of inflammatory responses at the beginning of antiinflammatory test [0.5 hour interval] in the high dose group. They further clarified that a sharp decline of paw circumference during 0.5 to $3.5 \mathrm{~h}$ supported the hypothesis. ${ }^{19}$ The study by Devaraj A et al demonstrated that the AEAVproduced dose-dependent and significant inhibition of carrageenan-induced paw edema which was comparable with the standard drug Indomethacin. ${ }^{24}$

We used the Granuloma Pouch Method induced by Carrageenan for studying the Anti-Sub-acute inflammatory property of Aloe vera. The exudate collected from the group treated with Aloe vera was $2.64 \pm 0.09 \mathrm{ml}$ with a $33.83 \%$ inhibition of exudate formation and from the group with the standard drug Indomethacin was $1.92 \pm 0.11 \mathrm{ml}$, accounting for $51.88 \%$ inhibition of exudate formation. Both the test drug i.e. AEAV[AEAV] at the dose of $500 \mathrm{mg} / \mathrm{kg}$ and the standard drug Indomethacin showed highly significant inhibition of exudate formation [ $p<0.01]$ when compared with the control. The study by Devaraj A et al earlier had shown the same results. They explained with the Cotton pellet granuloma pouch model that granulomatous tissue formation was significantly reduced with the administration of Aloe vera. ${ }^{24}$

To test the efficacy of Aloe vera against chronic inflammation, we used adjuvant induced arthritis method induced by complete Freund's adjuvant. On the $5^{\text {th }}$ day, $500 \mathrm{mg} / \mathrm{kg}$ of AEAV[AEAV] showed significant antiinflammatory effect on primary lesions when compared to the control [ $19.82 \%$ inhibition of paw edema]. The standard drug Indomethacin at the dose of $10 \mathrm{mg} / \mathrm{kg}$ also produced highly significant $[\mathrm{p}<0.01]$ anti-inflammatory effect in comparison to the control [37.84\%]. On the $21^{\text {st }}$ day the percentage inhibition for both Aloe vera and Indomethacin further increased, $66.67 \%$ for Aloe vera and $83.33 \%$ for Indomethacin. These results were highly significant when it was compared with the controlled group. These results are supported by Kshirsagar et al which illustrated that standard drug Diclofenac sodium and test drugs AE and AEC significantly suppressed the paw edema swelling induced by the complete Freund's adjuvant [CFA], around tibiotarsal joint and paws. ${ }^{21}$

On the Arthritic Index study by Kshirsagar AD et al groups treated with $\mathrm{AE} 50 \mathrm{mg} / \mathrm{kg}, \mathrm{AE}$ [aloe emodin] $75 \mathrm{mg} / \mathrm{kg}$, AEC $50 \mathrm{mg} / \mathrm{kg}$, and AEC $75 \mathrm{mg} / \mathrm{kg}$ showed significant decrease in the arthritic index, on the 21 st and $28^{\text {th }}$ day, respectively, while AEC $25 \mathrm{mg} / \mathrm{kg}$ treated groups showed significant decrease in the arthritic index on the 28th day as compared to arthritic control. ${ }^{20}$ The result of this study was parallel with our study. The arthritic index for Aloe vera at the dose of $500 \mathrm{mg} / \mathrm{kg}$ was $4 \pm 0.37$ and for the standard drug Indomethacin was $3.33 \pm 0.49$. These results were highly significant when it was compared with the control group $[\mathrm{p}<0.01]$ thereby establishing the anti-arthritic property of Aloe vera.

The study by Bhuvana KB et al mentions that AEAVhad shown anti-inflammatory effect in albino rats and the anti-inflammatory activity of Aloe vera is comparable to Indomethacin. However it also reveals that Aloe Vera also has antioxidant property, which may also be useful in various inflammatory disorders, as a secondary effect. $^{25}$

\section{CONCLUSION}

In spite of tremendous development in the field of synthetic drugs during recent era, they are found to have some or other side effects, whereas plants still hold their own unique place, by the way of having no side effects. Therefore, a systematic approach should be made to find out the efficacy of plants against inflammation so as to exploit them as herbal anti-inflammatory agents. Our 
study was an attempt to find the anti-inflammatory effect of Aloe vera which has been used since ages in almost all parts of the world. At this point it can be concluded that the AEAVat the dose of $500 \mathrm{mg} / \mathrm{kg}$ demonstrated appreciable anti-inflammatory effect. It showed significant anti-inflammatory activity against the experimental models of acute inflammation, sub-acute inflammation and chronic inflammation. A number of studies will be required in the future so that its safety is established.

Funding: No funding sources

Conflict of interest: None declared

Ethical approval: The study was approved by the Institutional Ethics Committee

\section{REFERENCES}

1. Kumar V, Abbas AK, Aster JC. Inflammation and repair. Robbins and Cotran Pathologic Basis of Disease. 9th edition. New Delhi: Elsevier; 2014:69-111.

2. Libby P. Inflammatory Mechanisms: The Molecular Basis of Inflammation and Disease. Nutrition Reviews. 2007;65(12):S140-6.

3. LM Buja, Krueger GRF. Netters Illustrated Human Pathology. 2ndedition. Philadelphia: Elsevier; 2014:5-6.

4. Balmuth D, Ringer N. 24 Safe and Effective Herbs to Know, Grow, and Use Rosemary Gladstar's Medicinal Herbs. United States: Storey Publishing; 2012:103-06.

5. Mwale M, Masika PJ. Analgesic and anti-inflammatory activities of Aloe ferox Mill. Aqueous extract. African Journal of Pharmacy and Pharmacology. 2010;4(6):2917.

6. Steenkamp V, Stewart MJ. Medicinal applications and toxicological activities of Aloe products. Pharm. Biol. 2007;45:411-20.

7. WHO monographs on selected medicinal plants. Health Organization Geneva. 1999;1:33-42.

8. Vane JR, Botting RM. New insights into the mode of action of anti-inflammatory drugs. Inflammation Res. 1995;44:1-10.

9. Saritha V, Anilakumar KR. Toxicological evaluation of methanol extract of Aloe vera in rats. International Journal on Pharmaceutical and Biomedical Research. 2010;1(5):142-9.

10. Subramani V, Kamaraj M, Ramachandran B, Jeyakumar JJ. Study of trace metals concentration and antimicrobial properties of tropical Aloe vera plant from Southern India. Int J of Phy. 2014;4(3):89-91.

11. Gerhard Vogel H. Antiarthrotic and immunomodulatory activity. Drug discovery and evaluation. Second completely revised updated and enlarged edition. Germany: Springer publication; 2002:802-805.
12. Dutta S, Das S. A study of the anti-inflammatory effect of the leaves of Psidium guajava Linn. on experimental animal models. Pharmacognosy Research. 2010;2(5):313-7.

13. Mujumdar AM, Misar AV. Anti-inflammatory activity of Jatropha curcas roots in mice and rats. $\mathrm{J}$ of Eth. 2004;90:11-5.

14. Agus S. The Potency of Piperine as Antiinflammatory and Analgesic in rats and mice. Folia Med Indonesiana. 2005;41:190-4.

15. Agrawal SS, Paridhavi M. Screening methods used for herbal drugs. Herbal drug technology. Hyderabad: universities press; 2007:583-7.

16. Bonney RJ. Obtaining mononuclear phagocytes from granulomas. Methods for Studying Mononuclear Phagocytes. Dolph Adams. London: Academic press; 1981:112-113.

17. Hambleton P, Miller P. Studies on carrageenin air pouch inflammation in the rat. The British Journal of Experimental Pathology. 1989;70:425-33.

18. Fukuhara I, Tsurufuji S. The effect of locally injected anti-inflammatory drugs on Carrageenan induced granuloma in rats. Biochemical Pharmacology. 1969;18:475-84.

19. Bhattacharjee S, Paul S, Dutta S, Chaudhuri TK. Antiinflammatory and protective properties of aloe vera leaf crude gel in carrageenan induced acute inflammatory rat models. Int J Pharm Sci. 2014;(9):368-71.

20. Geboes L, Klerck BD, Balen MV, Kelchtermans H, Mitera T, Boon L, et al. Freund's Complete Adjuvant Induces Arthritis in Mice Lacking a Functional Interferon- Receptor by Triggering Tumor Necrosis Factor-Driven Osteoclastogenesis. Arthritis and Rheumatism. 2007;56(8):2595-607.

21. Kshirsagar AD, Panchal PV, Harle UN, Nanda RK, Shaikh HM. Anti-Inflammatory and Antiarthritic Activity of Anthraquinone Derivatives in Rodents. International Journal of Inflammation. 2014:1-12.

22. Egesie UG, Chima KE, Galam NZ. Anti-inflammatory and Analgesic Effects of AEAV [Aloe barbadensis] in Rats. Afr. J. Biomed. Res. 2011;14:209-12.

23. Derbe T, Yilma B, Badasa S. Investigation of AntiBacterial And Anti-Oxidant Activities Of Aloe Vera Plant At Arba Minch, Southern Ethiopia. World J of Pha and Pha Sci. 2015;4(01):185-95.

24. Devaraj A, Karpagam T. Evaluation of antiinflammatory activity and analgesic effect of Aloe Vera leaf extract in rats. Int Res J of Pha. 2011;2(3):103-10.

25. Bhuvana KB, Hema NG. An Evaluation of Aloe Vera for its Acute Anti-inflammatory Activity in rat peritonitis model. World J of Pha Res. 2014;3(3):450819.

Cite this article as: Choudhury D, Roy D.

Evaluation of anti-inflammatory effect of aqueous extract of Aloe vera in Albino rats. Int $\mathrm{J}$ Basic Clin Pharmacol 2016;5:2488-95. 